\title{
Molecular genetic studies on abiotic stress resistance in sorghum entries through using half diallel analysis and inter-simple sequence repeat (ISSR) markers
}

\author{
Rasha Sabry Tawfik ${ }^{1}$ and Almoataz Bellah Ali El-Mouhamady²*
}

\begin{abstract}
Background: Water deficit stress is considered as one of the most important environmental stresses which is more harmful to strategic crops, as it reduces the final crop yield by up to 40\%. Therefore, the aim of this research is to evaluate some promising and superior sorghum entries for water stress tolerance and determine the most agromorphological parameters and reasons responsible for drought tolerance in this regard.

Results: Fifteenth sorghum genotypes (five parents and their ten F1 crosses resulting from half diallel analysis) were used in this investigation under two levels of irrigation (normal and drought experiment). The recent genotypes were estimated through some physiological parameters related to water stress tolerance in sorghum; besides that, eight inter-simple sequence repeat (ISSR) primers were used to identify among the five sorghum parents and the highest five crosses resistance to water deficit conditions depending on the data calculated from all studied traits under both conditions. The following genotypes P1, P2, P3, P1 $\times$ P2, P1 $\times$ P3, P2 $\times$ P3, P2 $\times$ P4, and P3 $\times$ P4 confirmed high resistance to water deficit conditions under the drought treatment compared with the control. This high resistance was affirmed through the calculated data for all studied traits. The ISSR profile analysis showed 151 fragments as taxonomic divisions among the ten sorghum genotypes (38 of them were monomorphic and 113 polymorphic with $74.83 \%$ polymorphism).

Conclusion: The entries $(\mathrm{P} 1, \mathrm{P} 2, \mathrm{P} 3, \mathrm{P} 1 \times \mathrm{P} 2, \mathrm{P} 1 \times \mathrm{P} 3, \mathrm{P} 2 \times \mathrm{P} 3, \mathrm{P} 2 \times \mathrm{P} 4$, and $\mathrm{P} 3 \times \mathrm{P} 4)$ were succeeded in achieving the highest concept of water deficit resistance under both conditions. Therefore, this work will be the nucleus for producing resistant sorghum varieties for drought stress in the future.
\end{abstract}

Keywords: Sorghum, Half diallel analysis, Drought, Water stress conditions, Agro-morphological traits, Additive and dominance gene action, Resistance, Tolerance, ISSR markers

\section{Background}

Sorghum is considering an important summer grain crop in Egypt. The phenomenon of water deficit or water poverty is one of the most important environmental obstacles that limit and hinder the productivity of different crops and plants, as it reduces productivity to the level up to $40-50 \%$, especially in the germination stage and the final outcome will be very low. But we see

\footnotetext{
* Correspondence: elmouhamady@yahoo.com

${ }^{2}$ Department of Genetics and Cytology, Genetic Engineering and

Biotechnology Division, National Research Centre, 33 El Buhouth ST, 12622,

Dokki, Giza, Egypt

Full list of author information is available at the end of the article
}

that a very large sector of important crops for humans is exposed to this dangerous environmental factor, especially the sorghum crop. Therefore, the results of the researchers will be reviewed in this regard. El-Mouhamady et al. (2016) studied the impact of water stress in some wheat entries through determining some physiological traits under the control treatment and drought experiment beside using six RAPD primers and confirmed that the genotypes Sakha 8, Sakha 94, Sakha $8 \times$ Sakha 93, Sakha $8 \times$ Sakha 94, and Sakha $8 \times$ Shandweel were the highest entries for water deficit tolerance; in addition, Eldessouky et al. (2016) studied 
water stress tolerance in some rice entries and observed 52 amplicons were generated through using seven intersimple sequence repeat (ISSR) primers for comparing among the previous genotypes. The impact of water stress on some barley genotypes was revealed by Ramadan et al. (2016) through estimating some agromorphological traits under normal and drought conditions besides comparing them using five RAPD primers. Twenty-one cross and one standard check variety of maize were estimated under normal and water deficit conditions to study the impact of drought stress on these entries through determining standard heterosis and general and specific combining ability effects and evaluated genetic diversity for the previous materials using five primers of ISSR, Esmail et al. (2016). Khatab et al. (2017) evaluated water stress tolerance on some sorghum genotypes through studying some physiological traits under normal and water stress conditions and the results confirmed that some entries such as PI534175, CD550190, and CPI456765 $\times$ PI534175 were exhibited highly resistance for drought tolerance for all studied traits under all conditions. The most and biggest values of water stress tolerance indices were estimated by Jabereldar et al. (2017) through estimating five sorghum accessions under three levels of water stress, and the final results detected that the highest mean yielding was showed in the sorghum cultivar (Taggat 14) which confirmed high tolerance for drought stress. Kalindee et al. (2018) found that sorghum seed bacterialization was considered highly resistance for water deficit conditions through determining proline content in sorghum leaves and this action was in corporeal up to the normal treatment at squeaky water stress condition wherein soil dampness was in the domain of 8 to $20 \%$.

Increase of tolerance and the performance of sorghum entries for saline and water deficit circumstances were showed predominately when employing seeds of highly resistance entry (BRS 330) submitted to hormonal priming at $100 \mathrm{ppm}$ GA3 condensation (Pinheiro et al. 2018). Too et al. (2018) instructed the resistance of sorghum bicolor for various stresses at the molecular level such as high limit of aluminum. There are four various kinds of techniques which assist in delivering sorghum plants for water stress such as evasion, eschewal, and bearing beside water deficit resuscitation. Moisture deficit condition competence occurs at any degree of crop growth ranging from seedling establishment, vegetative period, panicle improvement after-flowering, time among grain padding, to physiological precocity. Drought reactions in sorghum entries can be of physiological, morphological, and phonological kind (Verma et al. 2018). After the great destruction caused by drought stress in sorghum crop of $40-50 \%$, especially in the early stages of life, we can say that the real motive of this study is screening the most important sorghum genotype's resistance to water stress during all hybridizations carried out in this study to reach resistance lines that are the basis for producing sorghum varieties' tolerance for drought stress under Egyptian conditions in the future .

\section{Materials and methods}

Erect five accessions of sorghum (Sorghum vulgare) with different reaction to water deficit resistance were used in this study. This experiment was done in the farm of the National Research Centre in Nubaria, Behira Governorate, Egypt, during the period from 1 June 2017 to 21 September 2018. The five parents were sown in three planting dates with 5-day intervals in order to overcome the differences in flowering time among parents for crossing in 1 June 2017. All entries (parents and their F1 crosses) were grown under normal and drought conditions in a randomized complete block design with three replicates for each experiment in the farm of Nubaria in Behira Governorate, Egypt, in 1 June 2018, and all genotypes were harvested in 21 September 2018; in addition, all studied traits were evaluated and calculated under normal and drought conditions in the same season as follows:

- Studied traits: (1) Grain yield per plant (g): recorded as the weight of grain yield of each individual plant and adjusted to $14 \%$ moisture content, (2) maximum root length $(\mathrm{cm})$ : measured (in centimeters) from the tillering plateau to the longest root tip, (3) number of roots per plant: the total number of secondary and tertiary roots of each single plant was counted $2 \mathrm{~cm}$ below the tillering plateau, (4) root dry weight: all roots of each single plant were collected and oven-dried at $55{ }^{\circ} \mathrm{C}$ for 5 days and weighted (in grams), (5) osmotic pressure (MP): values of the total soluble solids of the cell sap were obtained for the pressed sap of the (fourth upper leaf) tested plants using the Abbe reflectometer and the osmotic pressure values (in atmosphere) were calculated by using special tables according to the methods described by Gosev (1960), (6) the proline content: determined from a standard curve and calculated on a fresh basis as follows: [( $\mu$ g proline/ $\mathrm{ml} \mathrm{C} \mathrm{ml} \mathrm{toluence}) / 115.5 \mu \mathrm{g} / \mu$ mole $] /[(\mathrm{g}$ sample $/ 5)]=$ $\mu \mathrm{mol}$ proline/g of fresh weight material. The results related to proline content are average values of at least 3-4 samples for each species, according to Chinard (1952) and a modified method by Bates et al. (1973), (7) $\Delta T$ values: temperature of canopy temperature of air, and (8) SPAD values or chlorophyll content $\left(\mathrm{mg} / \mathrm{ds}^{-1}\right)$ : the total of chlorophyll content was determined by using a chlorophyll analytical apparatus (chlorophyll meter 5 PAD-502 Minolta Camera Co. Ltd., Japan). Five flag 
leaves were measured form the widest part of the leaf of the main culm for each plant in all replications.

- Plant materials: The three Egyptian sorghum cultivars (Giza 15, Giza 113, and Dorado) were performed from Sorghum Research Department, Field Crops Research Institute, Agricultural Research Center, Ministry of Agriculture in Egypt; in addition, two lines were imported where the first one (CYR3465-3-2) was imported from the USA and the second line (Malzetar) was from ICRISAT (International Crops Research Institute for the Semi-Arid Tropics), respectively.

- System of irrigation: Normal irrigation experiment is meaning that the first irrigate was done at agriculture day, the second irrigate was done after 21 days from the first one or agriculture irrigate; after this, the subsequent irrigation was conducted every 15 days and prevented it before harvesting with 20 days, while the water stress treatment means that no irrigation was added after the fourth irrigate or in the beginning of flowering stage (When the plant age is 52 days).

- Irrigation method: Sprinkler irrigation.

- Total plots of experiment: They were six plots (three for normal irrigation experiment, three for water stress treatment, and $100 \mathrm{~m}$ was a break or space among them to prevent leakage of nominated water from the normal experiment to drought treatment).

- The experimental plot area: $75.0 \mathrm{~m}^{2}$ (including 15 rows where each genotype was planted in a single row for each replicate); length of plot or row was 10 $\mathrm{m}, 7.5 \mathrm{~m}$ width, $50 \mathrm{~cm}$ between two rows and $20 \mathrm{~cm}$ space between two plants in a row.

- Note: Each treatment was analyzed as a randomized complete black design experiment.

- Estimation of tolerance indices: All tolerance indices were estimated according to Fischer and Maurer (1978), Bouslama and Schapaugh (1984), Lin et al. (1986), Hossain et al. (1990), Fernandez (1992), Gavuzzi et al. (1997), and Golestani and Assad (1998) as follows:

$\mathrm{MS}=\mathrm{YS}+\mathrm{YP} / 2, \mathrm{DTI}=\mathrm{YP}+\mathrm{YS} /$ mean of $\mathrm{YP}^{2}, \mathrm{GMP}$ $=(\mathrm{YP} \times \mathrm{YS})^{0.5}, \mathrm{YI}=\mathrm{YS} /$ mean of YS, YSI $=\mathrm{YS} / \mathrm{YP},(\mathrm{YR})$ $=1-\mathrm{YS} / \mathrm{YP}, \mathrm{DSI}=(1-\mathrm{YD} / \mathrm{YW}) / \mathrm{D}$.

- Estimates of genetic parameters: The relative importance (RI) of general and specific combining abilities on progeny performance (i.e., the ratio between additives vs. total genetic variance components) was estimated according to Betran et al. (2003). Broad-sense heritability $\mathrm{H}^{2}(\mathrm{BS})=(\mathrm{VG} /$ $\mathrm{VP} \times 100)$ and narrow-sense heritability $\mathrm{H}^{2}(\mathrm{NS})=$ $(\mathrm{VA} / \mathrm{VP} \times 100)$ were estimated according to Falconar and Mackay (1996); in addition, GCV\% = $\mathrm{GV} /$ mean $\times 100$ and $\mathrm{PCV} \%=\mathrm{Ph} . \mathrm{V} /$ mean $\times 100$.

\section{Statistical analysis}

All calculated data from all studied traits under the two experiments were analyzed using half diallel analysis Griffing (1956) model I, method II including heterosis over better parent, general and specific combining ability effects, respectively (Table 1).

\section{Molecular markers}

Molecular marker technique aimed to estimate the phylogenetic tree and relationships and stand on the fragments responsible for similarities and differences among various sorghum entries. So, this investigation studied the molecular variation generated between the five sorghum parents besides the best five hybrids resulting from them using half diallel analysis and verified high water stress tolerance under drought treatment conditions compared to the control experiment depending on the results obtained from all studied traits estimated under both types of irrigation technique (water stress and normal conditions). The five promising and selected crosses were $\mathrm{P} 1 \times \mathrm{P} 2, \mathrm{P} 1 \times \mathrm{P} 3, \mathrm{P} 2 \times \mathrm{P} 3, \mathrm{P} 2$ $\times \mathrm{P} 4$, and $\mathrm{P} 3 \times \mathrm{P} 4$, respectively.

\section{Genomic DNA extraction and PCR condition}

Total genomic DNA of all samples was extracted from green sorghum leaves using Qiagen DNeasy Plant Minikit following the protocol of the manufacturer (Qiagen Inc, Valencia, CA, USA). The quality of the extracted DNA was assessed on agarose gel electrophoresis. PCR was performed using eight preselected ISSR primers based on their ability to generate reproducible and informative amplification patterns. Amplification reactions were carried out in Biometra $\mathrm{T}$ One Thermal Cycler (Analytik Jena, Jena, Germany). PCR amplification was performed in $25 \mu \mathrm{l}$ reaction mix which contained 20-30 ng DNA template, $10 \mathrm{pmol}$ of each primer, $2.5 \mu \mathrm{l}$ of 2 mM Thermo dNTPs, $5 \mu$ of $5 \mathrm{X}$ Promega Green GoTaq Flexi Reaction Buffer, $2.5 \mu \mathrm{l}$ of $25 \mathrm{mM}$ Promega $\mathrm{MgCl}_{2}$, and $0.125 \mu \mathrm{l}$ of $5 \mathrm{U} / \mu \mathrm{l}$ Promega GoTaq Flexi DNA polymerase. The reaction was assembled on ice, and amplification was performed at certain conditions as follows: an initial denaturing step at $94{ }^{\circ} \mathrm{C}$ for 5 min followed by 35 cycles at $94{ }^{\circ} \mathrm{C}$ for $30 \mathrm{~s}$, annealing at $50{ }^{\circ} \mathrm{C}$ for $1 \mathrm{~min}$, an extension at $72{ }^{\circ} \mathrm{C}$ for $1 \mathrm{~min}$, and final extension at

Table 1 Classification of the five sorghum parents used in a half diallel analysis

\begin{tabular}{llll}
\hline Serial no. & Names of genotypes & Origin & Drought tolerance \\
\hline 1 & Line one (CYR3465-3-2) & USA & Tolerance \\
2 & Line two (Malzetar) & ICRISAT & Tolerance \\
3 & Giza 15 & Egypt & Tolerance \\
4 & Giza 113 & Egypt & Moderate \\
5 & Dorado & Egypt & Moderate \\
\hline
\end{tabular}


$72{ }^{\circ} \mathrm{C}$ for $7 \mathrm{~min}$. The PCR products were assessed on 1.6\% agarose gel (Sambrook et al. 1989, Zietkiewicz et al. 1994, Gezahegn et al. 2010). The banding profile of ISSR were scored using the Labimage program, and the polymorphism percentage was estimated as follows

Percent of polymorphism $=$ (number of polymorphic bands/total number of bands) $\times 100$ (Table 2).

\section{Data handling and cluster analysis (phylogenetic tree)}

Data was scored for computer analysis on the basis of the presence or absence of the amplified products for each primer. Pairwise components of the ten genotypes based on the presence or absence of unique and shared polymorphic products, were used to determine similarity coefficients according to Jaccard (1908). The similarity coefficients were then used to construct dendrograms, using the un weighted pair group method with arithmetic averages (UPGMA) employing the SAHN (sequential, agglomerative, hierarchical, and nested clustering) from the NTSYS-PC (Numerical Taxonomy and Multivariate Analysis System), version 1.80 (Applied Biostatistics Program).

\section{Results}

\section{Mean performance}

After obtaining the results of the mean performance shown in Table 3 for all genotypes tested under normal irrigation and water deficit conditions, it can be summarized that the parent numbers $(1,2,3)$, as well as the crosses $\mathrm{P} 1 \times \mathrm{P} 2, \mathrm{P} 1 \times \mathrm{P} 3, \mathrm{P} 2 \times \mathrm{P} 3, \mathrm{P} 2 \times \mathrm{P} 4$ and $\mathrm{P} 3 \times \mathrm{P} 4$, recorded the highest values of traits: grain yield/plant, root dry weight, and maximum root length related to reach the water stored in the deep layers of soil during the occurrence of water stress; in addition, they increased the number of roots/plant, especially the adventitious or epigenetic roots form root system which can protect plant life during water stress. It was also observed that the previous superior genotypes had increased the rates of proline and chlorophyll contents in leaves under drought conditions compared to the

Table 2 Name and sequences of the selected ISSR primers used in ISSR analysis

\begin{tabular}{ll}
\hline Primer name & Sequence $\left(5^{\prime} \rightarrow\right.$ 3 $\left.^{\prime}\right)$ \\
\hline SR-04 & 5-ACACACACACACACACYA-3 (18 mer) \\
SR-05 & 5-ACACACACACACACACYC-3 (18 mer) \\
SR-06 & 5-ACACACACACACACACYG-3 (18 mer) \\
SR-07 & 5-ACACACACACACACACYT-3 (18 mer) \\
SR-11 & 5-AGAGAGAGAGAGAGAGT-3 (17 mer) \\
SR-12 & 5-AGAGAGAGAGAGAGAGYA-3 (18 mer) \\
SR-13 & 5-AGAGAGAGAGAGAGAGYC-3 (18 mer) \\
SR-14 & 5-AGAGAGAGAGAGAGAGYC-3 (18 mer) \\
\hline
\end{tabular}

normal irrigation and finally maintained low scores of osmotic pressure and $\Delta T$ during water stress compared to standard treatment, respectively.

\section{Analysis of variance}

The data revealed and detected in Table 4 exhibited that mean squares of all traits under testing showed highly significant variances under normal and water stress conditions and the same consequences were observed for the mean squares of GCA and SCA effects for the same traits under the same treatments which revealed the impact and importance of both additive and nonadditive types of gene action in controlling the inheritance and showing of all studied traits. These results showed in Table 4 also emphasized that the ratio of GCA/SCA was less than the unity for all characters studied for both treatments of irrigation. This means that non-additive gene action (dominance variance) and its interaction had high impact on controlling and inheriting the recent characters together under the types of irrigation. Afterwards, the selection method will be very substantial and functioned through using a bulk method technique, not a pedigree method.

\section{Heterosis over better parent}

The results detected in Table 5 showed that the entries $(\mathrm{P} 1 \times \mathrm{P} 2, \mathrm{P} 1 \times \mathrm{P} 3, \mathrm{P} 2 \times \mathrm{P} 3, \mathrm{P} 2 \times \mathrm{P} 4$, and $\mathrm{P} 3 \times \mathrm{P} 4)$ recorded significant and highly significant positive values for the traits (grain yield/plant, maximum root length, number of roots/plant, root dry weight, proline content, and SPAD values) under the control treatment and water deficit conditions, while the previous genotypes have not revealed any significance for osmotic pressure and $\Delta T$ traits under both conditions where it exhibited no significance and negative values, respectively.

\section{General and specific combining ability effects}

Highly significant positive values were observed in the parents (P1, P2, and P3) for GCA effects under both types of irrigation (normal and water stress conditions) in Table 6, which indicated the importance of additive and additive $\times$ additive types of gene action for controlling and inheriting the previous traits under normal and water deficit treatments besides the fruitful contribution for enhancing and increasing the ability of water stress tolerance in these parents. In the same conversation, the results revealed in Table 7 for SCA effects confirmed that the entries $(\mathrm{P} 1 \times \mathrm{P} 2, \mathrm{P} 1 \times \mathrm{P} 3, \mathrm{P} 2 \times \mathrm{P} 3, \mathrm{P} 2 \times \mathrm{P} 4$, and $\mathrm{P} 3 \times \mathrm{P} 4)$ exhibited highly significant and positive values for this parameter under the control treatment and water stress experiment which detected the importance of dominance and dominance $x$ dominance types of gene action and reflected with a direct form on the 
Table 3 Mean performances of all entries for all studied traits in sorghum accessions under the control treatment of irrigation and water stress conditions

\begin{tabular}{|c|c|c|c|c|c|c|c|c|c|c|c|c|c|c|c|c|}
\hline \multirow[t]{2}{*}{ Entries } & \multicolumn{2}{|l|}{ GY/P } & \multicolumn{2}{|l|}{ MRL } & \multicolumn{2}{|c|}{ No. of $R / P$} & \multicolumn{2}{|l|}{ RDW } & \multicolumn{2}{|l|}{$\mathrm{OP}$} & \multicolumn{2}{|c|}{ Proline C. } & \multicolumn{2}{|l|}{$\Delta T$} & \multicolumn{2}{|c|}{ SPAD values } \\
\hline & $\mathrm{CT}$ & DT & $\mathrm{CT}$ & DT & $\mathrm{CT}$ & DT & $C T$ & DT & $C T$ & DT & $\mathrm{CT}$ & DT & $\mathrm{CT}$ & DT & $\mathrm{CT}$ & DT \\
\hline P1 & 52.88 & 47.45 & 71.79 & 65.44 & 488.22 & 429.55 & 12.36 & 11.18 & 1.38 & 1.26 & 67.33 & 58.04 & 1.58 & 1.14 & 59.63 & 48.16 \\
\hline P2 & 41.39 & 36.13 & 57.14 & 48.11 & 547.26 & 490.55 & 13.87 & 10.54 & 1.15 & 1.07 & 71.88 & 63.15 & 1.83 & 1.33 & 48.71 & 44.36 \\
\hline P3 & 48.66 & 42.50 & 63.32 & 57.60 & 588.39 & 555.16 & 11.15 & 9.77 & 1.44 & 1.15 & 59.40 & 48.41 & 2.38 & 1.57 & 65.34 & 53.21 \\
\hline P4 & 35.70 & 27.83 & 43.20 & 28.17 & 346.55 & 238.41 & 7.42 & 4.19 & 2.55 & 2.87 & 38.25 & 33.09 & 3.89 & 4.12 & 35.24 & 21.78 \\
\hline P5 & 38.44 & 32.67 & 34.88 & 25.56 & 390.58 & 267.37 & 5.81 & 3.96 & 2.36 & 2.69 & 41.50 & 31.17 & 2.49 & 3.77 & 38.39 & 27.43 \\
\hline $\mathrm{P} 1 \times \mathrm{P} 2$ & 64.46 & 50.32 & 86.39 & 77.55 & 704.28 & 639.62 & 16.08 & 14.30 & 1.03 & 0.78 & 85.16 & 71.05 & 1.51 & 0.99 & 73.40 & 61.18 \\
\hline $\mathrm{P} 1 \times \mathrm{P} 3$ & 58.37 & 54.34 & 79.58 & 74.49 & 699.42 & 584.12 & 15.60 & 12.57 & 1.16 & 1.02 & 74.44 & 63.13 & 1.29 & 1.09 & 83.72 & 68.55 \\
\hline $\mathrm{P} 1 \times \mathrm{P} 4$ & 28.70 & 21.53 & 42.77 & 25.28 & 288.69 & 187.66 & 6.11 & 4.05 & 2.87 & 3.15 & 37.03 & 29.97 & 4.04 & 5.55 & 33.03 & 18.55 \\
\hline $1 \times \mathrm{P} 5$ & 31.19 & 24.57 & 29.48 & 21.11 & 314.36 & 224.83 & 5.39 & 2.18 & 2.79 & 3.44 & 34.0 & 25.06 & 2.87 & 4.69 & 28.65 & 24.38 \\
\hline $\mathrm{P} 2 \times \mathrm{P} 3$ & 59.37 & 48.57 & 69.88 & 62.38 & 745.44 & 622.80 & 17.08 & 13.56 & 0.89 & 0.71 & 89.42 & 77.29 & 1.81 & 1.28 & 77.94 & 59.18 \\
\hline $\mathrm{P} 2 \times \mathrm{P} 4$ & 55.46 & 43.78 & 75.46 & 67.89 & 623.44 & 574.51 & 17.27 & 15.98 & 0.67 & 0.55 & 97.20 & 83.87 & 1.63 & 0.97 & 57.33 & 55.16 \\
\hline $\mathrm{P} 2 \times \mathrm{P} 5$ & 37.05 & 28.26 & 33.40 & 20.59 & 312.64 & 173.79 & 3.78 & 2.03 & 2.85 & 3.68 & 29.37 & 18.34 & 2.68 & 4.07 & 27.66 & 19.48 \\
\hline $\mathrm{P} 3 \times \mathrm{P} 4$ & 61.88 & 55.46 & 84.16 & 72.13 & 785.11 & 694.05 & 12.79 & 11.58 & 1.19 & 1.03 & 66.27 & 59.18 & 1.91 & 1.16 & 85.27 & 68.14 \\
\hline $\mathrm{P} 3 \times \mathrm{P} 5$ & 38.20 & 23.70 & 29.17 & 23.22 & 356.58 & 241.26 & 4.59 & 1.85 & 3.06 & 3.43 & 40.11 & 26.0 & 3.95 & 4.25 & 36.50 & 25.71 \\
\hline $\mathrm{P} 4 \times \mathrm{P} 5$ & 25.28 & 19.65 & 34.57 & 22.84 & 329.14 & 189.47 & 3.14 & 2.48 & 2.64 & 2.97 & 27.43 & 23.64 & 4.37 & 4.23 & 34.86 & 20.13 \\
\hline LSD at 0.05 & 1.79 & 1.53 & 1.14 & 3.09 & 1.98 & 1.84 & 1.27 & 1.04 & 1.17 & 0.86 & 1.48 & 1.30 & 1.36 & 1.48 & 1.69 & 1.50 \\
\hline LSD at 0.01 & 2.60 & 2.22 & 1.66 & 4.48 & 2.88 & 2.67 & 1.84 & 1.52 & 1.71 & 1.25 & 2.15 & 1.88 & 1.98 & 2.16 & 2.45 & 2.18 \\
\hline
\end{tabular}

extent of the association of SCA effects with heterosis over better parent.

\section{Genetic components}

Data viewing in Table 8 revealed that the values of dominance variance were higher than the values of additive variance for all traits under investigation for the normal and water stress conditions except the traits grain yield/ plant and osmotic pressure for water deficit conditions, maximum root length for the control treatment, and number of roots/plant for both treatment which debated that dominance gene action (dominance variance) was played and achieved the indispensable and prolific role for controlling and inheriting the previous traits under study for both conditions of irrigation and confirmed that the selection process will be important in the late segregation generation firstly from the fourth generation to seventh generation or more, and this was for this case. In the case of additive gene action, it was higher than dominance variance. We can say that additive variance was the sole controller and principally responsible for inheriting and controlling grain yield/plant and osmotic pressure for water stress treatment, maximum root length for the normal conditions, and number of roots/plant for both types of irrigation and the selecting process will be fruitful for these traits in early segregation generation, respectively.

\section{Tolerance indices}

Results presented in Table 9 showed that the genotypes $(\mathrm{P} 1, \mathrm{P} 2, \mathrm{P} 3, \mathrm{P} 5, \mathrm{P} 1 \times \mathrm{P} 3, \mathrm{P} 2 \times \mathrm{P} 3, \mathrm{P} 3 \times \mathrm{P} 4)$ for YSI and $(\mathrm{P} 1, \mathrm{P} 2, \mathrm{P} 3, \mathrm{P} 1 \times \mathrm{P} 2, \mathrm{P} 1 \times \mathrm{P} 3, \mathrm{P} 2 \times \mathrm{P} 3, \mathrm{P} 2 \times \mathrm{P} 4, \mathrm{P} 3 \times$ $\mathrm{P} 4)$ for MP and GMP recorded the highest mean values for the tolerance index parameters in this study which revealed that these entries were highly tolerant of water stress conditions. On the same regard, the genotypes $(\mathrm{P} 1, \mathrm{P} 3, \mathrm{P} 1 \times \mathrm{P} 2, \mathrm{P} 1 \times \mathrm{P} 3, \mathrm{P} 2 \times \mathrm{P} 3, \mathrm{P} 2 \times \mathrm{P} 4, \mathrm{P} 3 \times \mathrm{P} 4)$ for YI and the same entries besides (P2) for DTI showed mean values higher than 1 which indicated that these entries recorded high resistance under water deficit conditions. In the opposite direction, all entries under investigation for YR and the genotypes (P1, P2, P3, P5, P1 $\times$ P3, and P3 $\times$ P4) for DSI exhibited results lower than the unity which confirmed that these genotypes revealed high tolerance and resistance to drought stress because they were attained at the highest level of output (grain yield/plant) under water deficit conditions compared with the normal treatment alongside; it minimized the proportion of grain yield wastage under water stress treatment like the control experiment.

\section{Molecular description using ISSR primers}

Data of the ISSR profile shown in Table 10 and Fig. 1 revealed that the analysis of eight ISSR primers showed 151 fragments, 38 of them were monomorphic and 113 bands were polymorphic with $74.83 \%$ polymorphism 


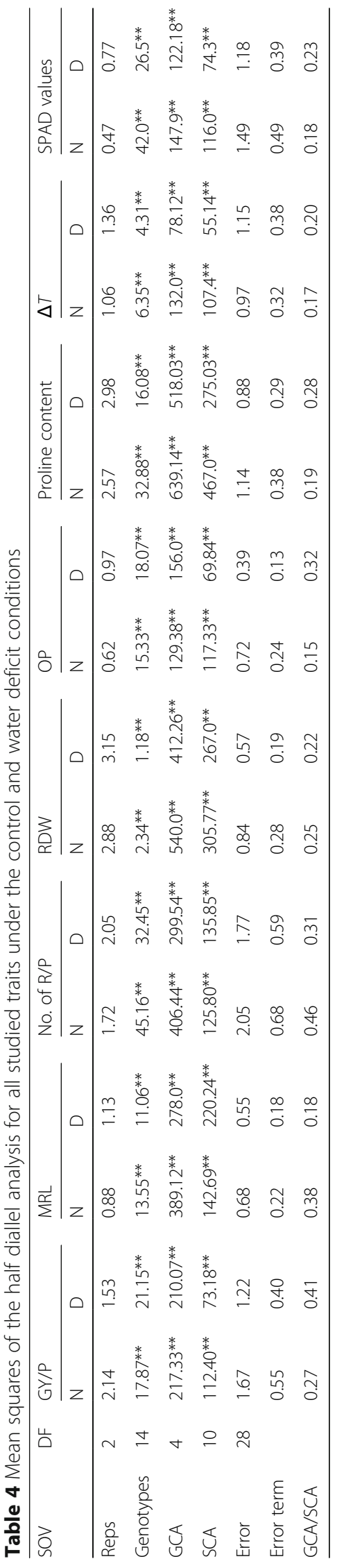




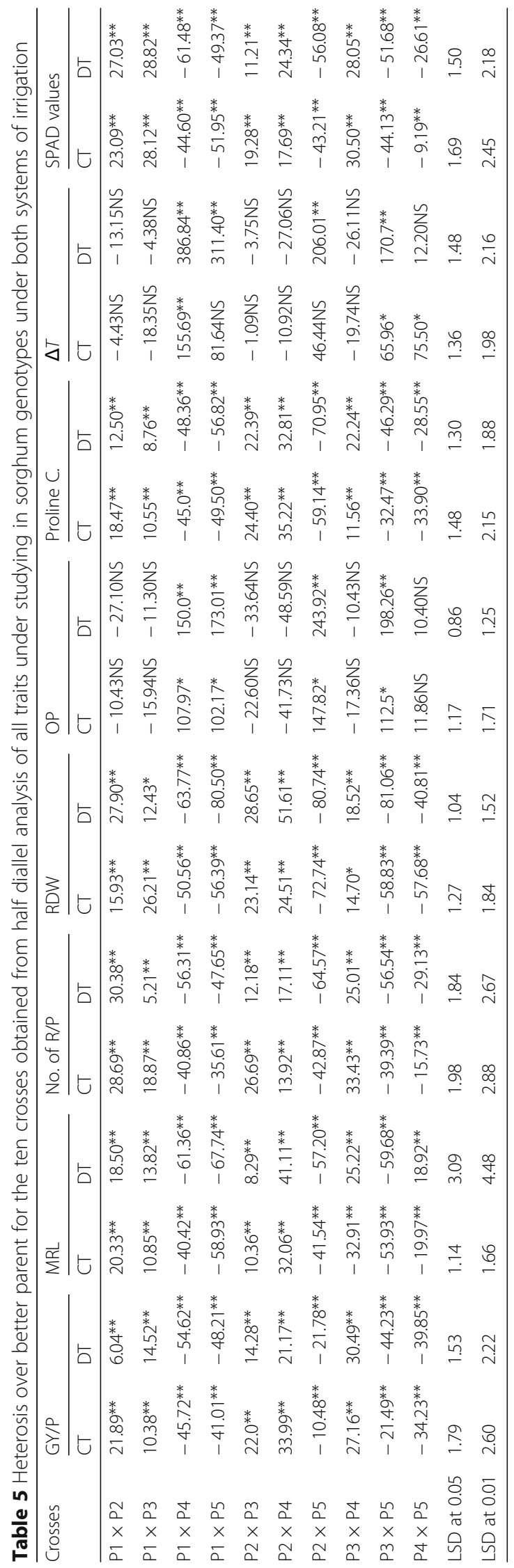




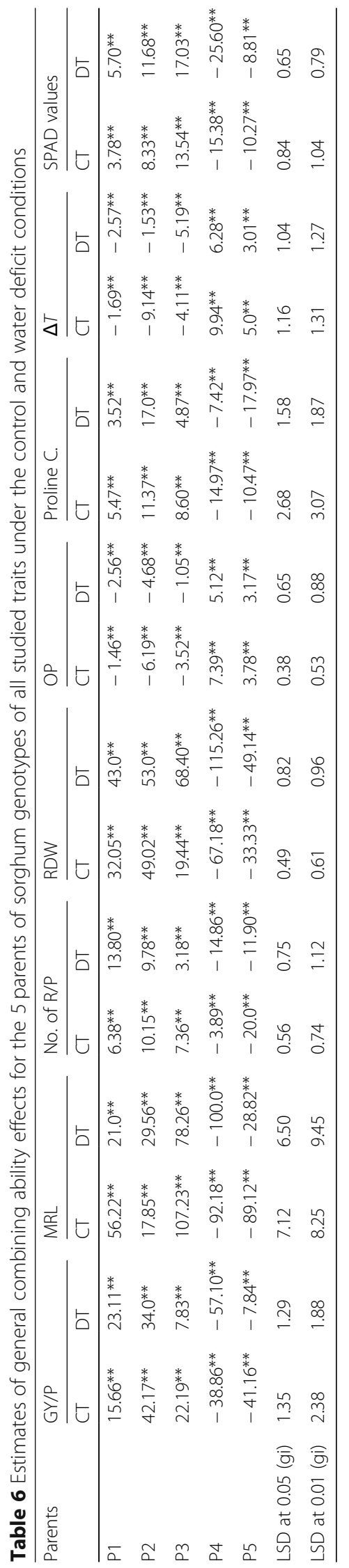




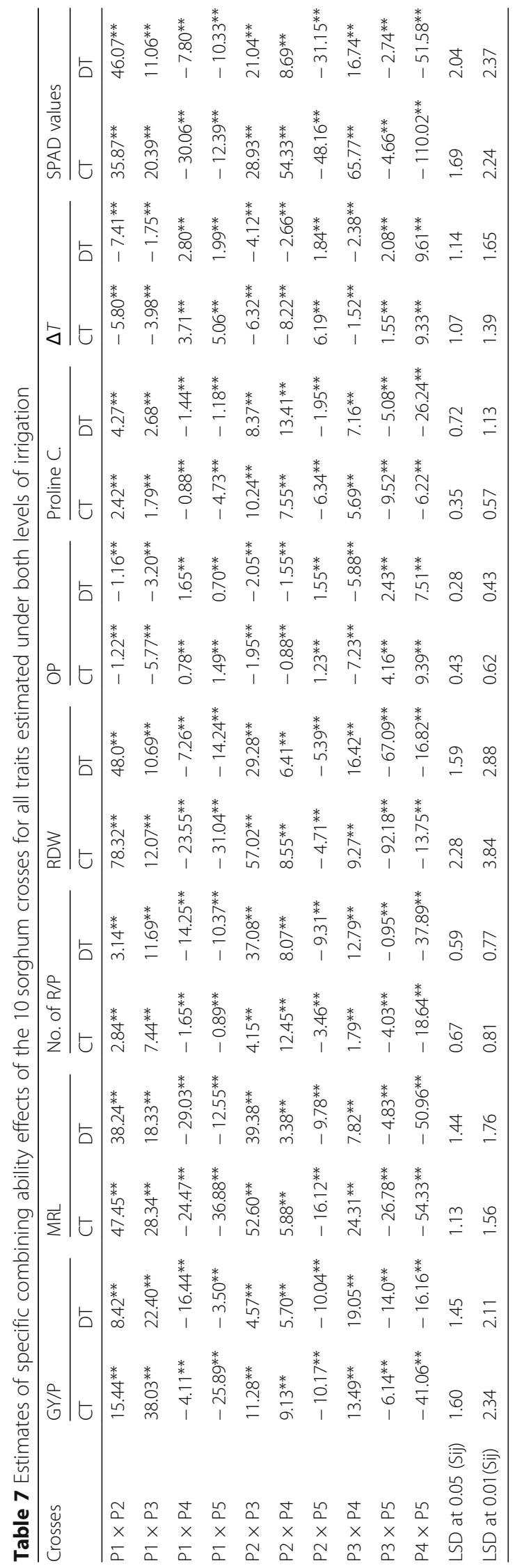


Table 8 Determination of all genetic parameters in all traits estimated under the control treatment and water deficit conditions

\begin{tabular}{|c|c|c|c|c|c|c|c|c|c|c|c|c|c|c|c|c|}
\hline \multirow{2}{*}{$\begin{array}{l}\text { Genetic } \\
\text { components }\end{array}$} & \multicolumn{2}{|l|}{ GY/P } & \multicolumn{2}{|l|}{ MRL } & \multicolumn{2}{|c|}{ No. of $R / P$} & \multicolumn{2}{|l|}{ RDW } & \multicolumn{2}{|l|}{$\mathrm{OP}$} & \multicolumn{2}{|c|}{ Proline $\mathrm{C}$. } & \multicolumn{2}{|l|}{$\Delta T$} & \multicolumn{2}{|c|}{ SPAD values } \\
\hline & CT & DT & CT & DT & CT & DT & CT & DT & $\mathrm{CT}$ & DT & $C T$ & DT & CT & DT & CT & DT \\
\hline Additive variance & 108.66 & 105.03 & 194.56 & 139.0 & 203.22 & 149.77 & 270.0 & 206.13 & 64.69 & 78.0 & 319.57 & 259.01 & 66.0 & 39.06 & 73.95 & 61.09 \\
\hline $\begin{array}{l}\text { Dominance } \\
\text { variance }\end{array}$ & 112.40 & 73.18 & 142.69 & 220.24 & 125.80 & 135.85 & 305.77 & 267.0 & 117.33 & 69.84 & 467.0 & 275.03 & 107.4 & 55.14 & 116.0 & 74.3 \\
\hline $\begin{array}{l}\text { Genotypic } \\
\text { variance }\end{array}$ & 221.06 & 178.21 & 337.25 & 359.24 & 329.02 & 285.62 & 575.77 & 473.13 & 182.02 & 147.84 & 786.57 & 534.04 & 173.4 & 94.2 & 189.95 & 135.39 \\
\hline $\begin{array}{l}\text { Environmental } \\
\text { variance }\end{array}$ & 0.55 & 0.40 & 0.22 & 0.18 & 0.68 & 0.59 & 0.28 & 0.19 & 0.24 & 0.13 & 0.38 & 0.29 & 0.32 & 0.38 & 0.49 & 0.39 \\
\hline $\begin{array}{l}\text { Phenotypic } \\
\text { variance }\end{array}$ & 221.61 & 178.61 & 337.47 & 359.42 & 329.7 & 286.21 & 576.05 & 473.32 & 182.26 & 147.97 & 786.95 & 534.33 & 173.72 & 94.58 & 190.44 & 135.78 \\
\hline Rl & 49.15 & 58.93 & 57.69 & 38.69 & 61.76 & 52.43 & 46.89 & 43.56 & 35.54 & 52.75 & 40.62 & 48.50 & 38.06 & 41.46 & 38.93 & 45.12 \\
\hline $\mathrm{H}^{2}(\mathrm{NS})$ & 49.03 & 58.80 & 57.65 & 38.67 & 61.63 & 52.32 & 46.87 & 43.54 & 35.49 & 52.71 & 40.60 & 48.47 & 37.99 & 41.29 & 38.83 & 44.99 \\
\hline $\mathrm{H}^{2}(\mathrm{BS})$ & 99.75 & 99.77 & 99.93 & 99.94 & 99.79 & 99.79 & 99.95 & 99.96 & 99.86 & 99.91 & 99.95 & 99.94 & 99.81 & 99.59 & 99.74 & 99.71 \\
\hline Mean & 45.13 & 37.11 & 55.67 & 46.15 & 501.34 & 407.54 & 10.16 & 8.01 & 1.86 & 1.98 & 57.25 & 47.42 & 2.54 & 2.68 & 52.37 & 41.02 \\
\hline GCV\% & 32.94 & 35.97 & 32.98 & 41.06 & 3.61 & 4.14 & 236.17 & 271.55 & 725.34 & 614.08 & 48.98 & 48.73 & 518.43 & 362.15 & 26.31 & 28.36 \\
\hline PCV\% & 32.98 & 36.01 & 32.99 & 41.07 & 3.62 & 4.15 & 236.23 & 271.61 & 725.82 & 614.35 & 49.0 & 48.74 & 518.90 & 362.88 & 26.35 & 28.40 \\
\hline
\end{tabular}

$\mathrm{RI}=1 / 2 \delta^{2} \mathrm{GCA} /\left(1 / 2 \delta^{2} \mathrm{GCA}+\delta^{2} \mathrm{SCA}\right) \times 100 ; \mathrm{H}^{2}(\mathrm{NS})=1 / 2 \delta^{2} \mathrm{GCA} /\left(1 / 2 \delta^{2} \mathrm{GCA}+\delta^{2} \mathrm{SCA}+\delta \mathrm{e}\right) \times 100 ; \mathrm{H}^{2}(\mathrm{BS})=\left(1 / 2 \delta^{2} \mathrm{GCA}+\delta^{2} \mathrm{SCA}\right) /\left(1 / 2 \delta^{2} \mathrm{GCA}+\delta^{2} \mathrm{SCA}+\delta^{2} \mathrm{e}\right) \times$ $100 ; \mathrm{GCV} \%=\mathrm{GV} / \mathrm{mean} \times 100 ; \mathrm{PCV} \%=\mathrm{PV} /$ mean $\times 100$

including 20 unique bands with a range size of 104 to $2131 \mathrm{bp}$. The first primer SR-04 detected 16 amplicons (6 of them were monomorphic and 10 polymorphic) with $62.50 \%$ polymorphism including 2 unique bands with sizes from 186 to $1671 \mathrm{bp}$, while the primer SR-05 produced 27 fragments (one of them was monomorphic and the other bands were polymorphic) with $96.29 \%$ polymorphism including 6 unique bands with sizes from

Table 9 Calculated the tolerance indices parameters for the sorghum genotypes especially for grain yield trait under the two treatments of irrigation

\begin{tabular}{|c|c|c|c|c|c|c|c|c|c|}
\hline S & YYP & GYD & YSI & Yl & MP & DTI & GMP & YR & DSI \\
\hline & 52.88 & 7.45 & 0.89 & 1.27 & 50.16 & 1.82 & 50.09 & 0.11 & 0.64 \\
\hline & & & & & & & & & 0.76 \\
\hline & 866 & 42.50 & 0.87 & 1.14 & 45.58 & 1.50 & & 0.13 & 0.76 \\
\hline & & & & & & 0.72 & 31.52 & 0.23 & 1.5 \\
\hline & 38.44 & 32.67 & 0.84 & 0.88 & 35.55 & 0.91 & 35.43 & 0.16 & 0.94 \\
\hline & & 50.32 & & 1.35 & & 2.35 & 56.95 & 0.22 & 1.2 \\
\hline$\times P 3$ & 58.37 & 54.34 & 0.93 & 1.46 & 56.35 & 2.30 & 56.31 & 0.07 & 0.4 \\
\hline $1 \times 17$ & 3.70 & 21.53 & 0.75 & 0.58 & & 0.44 & 24.85 & 0.25 & 1.47 \\
\hline$\times \mathrm{P} 5$ & 31.19 & 24.57 & 0.78 & 0.66 & 27.88 & 0.55 & 27.68 & 0.22 & 1.29 \\
\hline A & 7 & 48.57 & & 1.30 & & 2.09 & 53.69 & & 1.1 \\
\hline$Y P 4$ & 55.46 & 43.78 & 0.78 & 1.17 & 49.62 & 1.76 & 49.27 & 0.22 & 1.29 \\
\hline & 37.05 & 28.26 & 0.76 & 0.76 & & 0.76 & 32.35 & 0.24 & 1.4 \\
\hline $\mathrm{P} 3 \times \mathrm{P} 4$ & 61.88 & 55.46 & 0.89 & 1.49 & 58.67 & 2.49 & 58.58 & 0.11 & 0.64 \\
\hline $3 \times 53$ & 38.20 & 23.70 & 0.62 & 0.63 & 30.95 & 0.65 & 30.08 & 0.38 & 2.23 \\
\hline $4 \times P 5$ & 25.28 & 19.65 & 0.77 & 0.52 & 22.46 & 0.36 & 22.28 & 0.23 & 1.35 \\
\hline
\end{tabular}

156 to 1859 bp. Primer SR-06 generated 27 amplicons which consisted of 4 monomorphic and 23 polymorphic including 5 unique bands with $85.18 \%$ polymorphism with a size which ranged from 369 to $2131 \mathrm{bp}$, respectively. Primer SR-07 showed 17 fragments (5 of them were monomorphic and 12 polymorphic including 2 unique bands) with $70.58 \%$ polymorphism with sizes from 118 to $1346 \mathrm{bp}$, while 10 fragments were generated by the SR-11 primer where 6 of them were monomorphic and 4 polymorphic with $40 \%$ polymorphism with sizes from 119 to $1961 \mathrm{bp}$. For the primer SR-12, there were 20 amplicons where 7 of them were monomorphic and 13 polymorphic including one unique band with $65 \%$ polymorphism with sizes from 190 to $1491 \mathrm{bp}$, while the SR-13 primer showed 20 fragments (4 of them were monomorphic and 16 polymorphic including 3 unique bands) with $80 \%$ polymorphism with sizes from 110 to $1013 \mathrm{bp}$, and the last primer SR-14 generated 14 bands (5 of them were monomorphic and 9 polymorphic including one unique band) with $64.28 \%$ polymorphism with sizes from 104 to $1260 \mathrm{bp}$, respectively.

P5 and H3 exhibited the highest number of amplified fragments (102) together, but P1 recorded the lowest number (66) and the rest of the genotypes showed various numbers of bands (Table 11). In the same table, it is noted that primers SR-06 and SR-12 recorded the highest number of bands (130) together for all materials under study, while the SR-11 primer displayed the lowest number of amplified fragments (89) for the same entries. 
Table 10 The polymorphic loci amplified by the eight ISSR primers for the ten sorghum entries

\begin{tabular}{|c|c|c|c|c|c|c|}
\hline Primer Code & Loci & $\begin{array}{c}\text { Monomorphic } \\
\text { bands }\end{array}$ & $\begin{array}{c}\text { Polymorphic } \\
\text { bands }\end{array}$ & $\begin{array}{c}\text { Positive specific } \\
\text { bands } \\
\text { (Unique band) }\end{array}$ & Polymorphism \% & Range Size \\
\hline SR-04 & 16 & 6 & 10 & 2 & $62.50 \%$ & $186-1671$ bp \\
\hline SR-05 & 27 & 1 & 26 & 6 & $96.29 \%$ & $156-1859$ bp \\
\hline SR-06 & 27 & 4 & 23 & 5 & $85.18 \%$ & $369-2131$ bp \\
\hline SR-07 & 17 & 5 & 12 & 2 & $70.58 \%$ & $118-1346$ bp \\
\hline SR-11 & 10 & 6 & 4 & 0 & $40 \%$ & $119-1961$ bp \\
\hline SR-12 & 20 & 7 & 13 & 1 & $65 \%$ & $190-1491$ bp \\
\hline SR-13 & 20 & 4 & 16 & 3 & $80 \%$ & $110-1013$ bp \\
\hline SR-14 & 14 & 5 & 9 & 1 & $64.28 \%$ & $104-1260$ bp \\
\hline Total Loci & 151 & 38 & 113 & 20 & $74.83 \%$ & $104-2131$ bp \\
\hline
\end{tabular}

Data presented in Table 12 revealed positive and negative specific markers generated from eight ISSR primers using to identify among ten sorghum genotypes and results showed that the primer SR-04 exhibited three specific markers (one of them was showed for P3 with size $324 \mathrm{bp}$ and two positive markers for P4 and P5 with sizes 1671 and $711 \mathrm{bp}$ ), while the SR-05 primer generated 7 specific markers (six of them were positive markers consisting to 3 positive for P2 with sizes 913, 1627, and $1859 \mathrm{bp}, 2$ positive for $\mathrm{P} 4$ with sizes 790 and $1377 \mathrm{bp}$ and the last one for $\mathrm{H} 1$ with size $840 \mathrm{bp}$ ); besides, one negative marker was observed for $\mathrm{P} 4$ with a size of $320 \mathrm{bp}$, respectively. The SR-06 primer displayed 7 specific markers (5 of them were positive and 2 negative) and the positive markers were observed in $\mathrm{H} 3$ including 2 positive with sizes 1807 and 2131 bp; P2 including one positive with size $1230 \mathrm{bp}$; $\mathrm{H} 2$ containing one positive with size $983 \mathrm{bp}$; and $\mathrm{P} 1$ gave one positive with size $181 \mathrm{bp}$, while the two negative markers appeared in genotypes P1 and H2 with sizes 208 and 889 bp, respectively. For the SR-07 primer, three markers were generated through ISSR analysis where 2 positive markers were observed at H1 with sizes 302 and $1346 \mathrm{bp}$ and one negative appeared in P1 with size $463 \mathrm{bp}$, while the SR-11 primer exhibited one negative marker for P1 with $1213 \mathrm{bp}$. Results confirmed that the SR-12 primer showed two markers (one positive with size $1491 \mathrm{bp}$ for P2 and one negative with $560 \mathrm{bp}$ for $\mathrm{H} 2$ genotype). In the same trend, the SR-13 primer produced 3 positive markers ( 2 of them with sizes 254 and 529 bp showed in H5 genotype and the last one with size $281 \mathrm{bp}$ was observed in P4). The SR-14 primer displayed 4 specific markers (one of them was positive for P2 with a size of $705 \mathrm{bp}$ and 3 were negative (2 of them appeared in P1 with sizes 277 and $669 \mathrm{bp}$ and one negative was observed in P3 with size 104 bp)).

\section{Proximity matrix analysis (genetic similarity)}

Data shown in Table 13 displayed 45 pairwise comparisons to debate the genetic relationships among 10 sorghum genotypes detected in terms of similarity. The genetic similarity ranged from 0.460 to 0.824 with an average of 0.642 , where the biggest value of genetic similarity was 0.824 among P4 and P5 and the lowest value of similarity was 0.460 among P1 and H3. Highly genetic similarity values were obtained for example within P2 and $\mathrm{P} 5, \mathrm{P} 5$ and $\mathrm{H} 1, \mathrm{P} 5$ and $\mathrm{H} 3, \mathrm{H} 1$ and $\mathrm{H} 2, \mathrm{H} 3$ and $\mathrm{H} 4$, $\mathrm{H} 3$ and $\mathrm{H} 5$, and $\mathrm{H} 4$ and $\mathrm{H} 5$, and their values were $0.701,0.763,0.743,0.757,0.761,0.704$, and 0.801 , respectively. The other data of genetic similarity exhibited values which ranged from low to medium or slightly higher for example but not limited to 0.582, 0.490, $0.527,0.500,557,0.509,0.481,0.683,0.632,0.683$, and 0.689 among $\mathrm{P} 1$ and $\mathrm{P} 3, \mathrm{P} 1$ and $\mathrm{P} 4, \mathrm{P} 1$ and $\mathrm{P} 5, \mathrm{P} 1$ and $\mathrm{H} 1, \mathrm{P} 1$ and $\mathrm{H} 2, \mathrm{P} 1$ and $\mathrm{H} 4, \mathrm{P} 1$ and $\mathrm{H} 5, \mathrm{P} 2$ and P3, P3 and $\mathrm{P} 4, \mathrm{P} 4$ and $\mathrm{H} 3$, and $\mathrm{H} 1$ and $\mathrm{H} 3$, respectively.

\section{Cluster analysis (phylogenetic tree)}

Results obtained from the cluster analysis presented in Fig. 2 consisted all sorghum entries to two main clusters. Cluster I included P1 and one subcluster contained P2 and P3 genotypes, while cluster II consisted of two subclusters, where the first one included H3 and one set contained $\mathrm{H} 4$ and $\mathrm{H} 5$, but subcluster II contains two subsubclusters or two groups. Sub-subcluster I included H1 and $\mathrm{H} 2$, while sub-subcluster II contained P4 and P5.

\section{Discussion}

Results in Table 3 were confirmed the largest evidence for drought resistance of the previous sorghum entries under water deficit treatment compared to the control experiment because it has already succeeded in reducing water loss during the process of transpiration while 

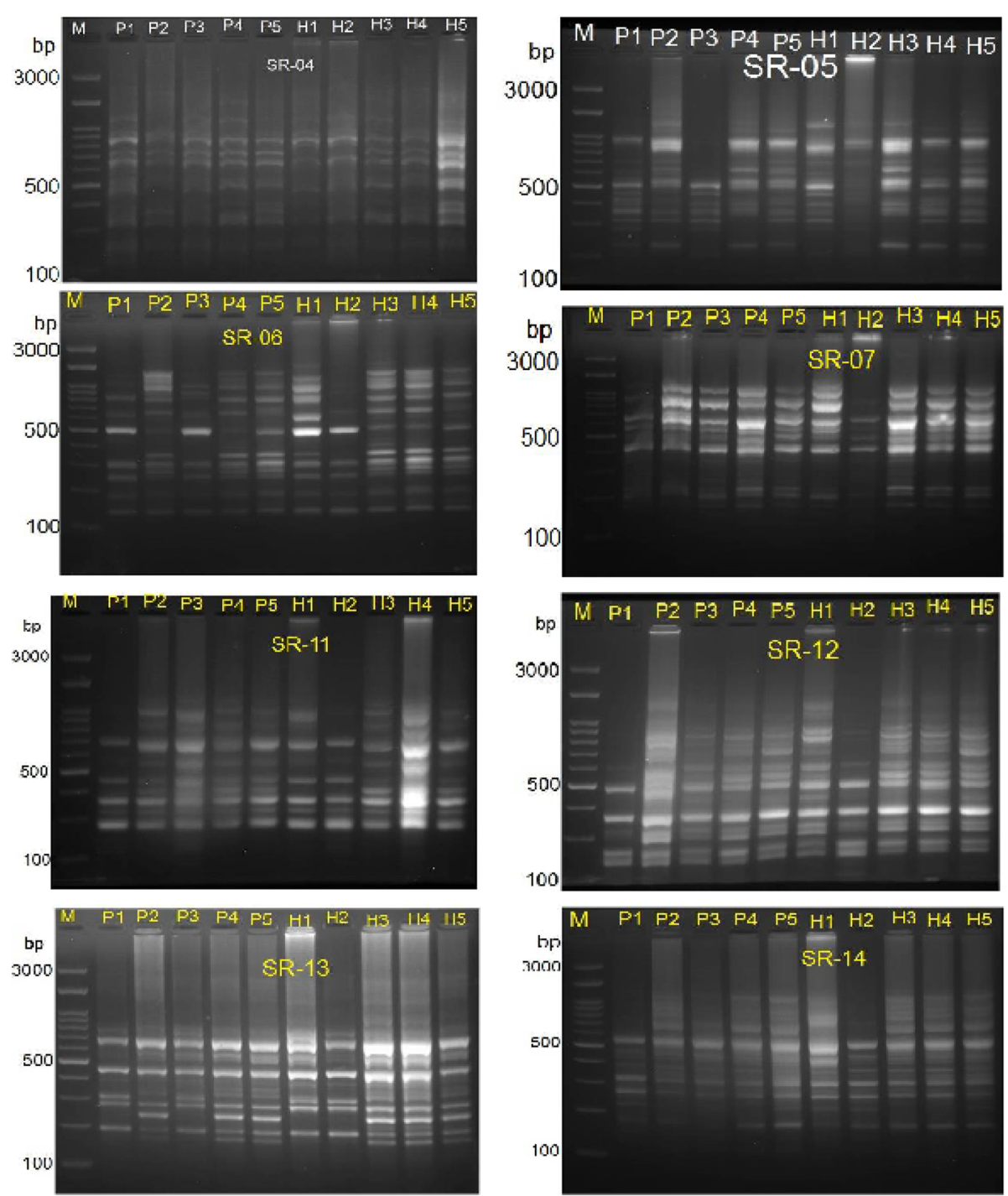

Fig. 1 PCRfragments with eight ISSR primers (SR-04, SR-05, SR-06, SR-07, SR-11, SR-12, SR-13, and SR-14) of ten sorghum entries (1:10) where P1: Line one (CYR3465-3-2), P2: Line two (Malzetar), P3: Giza 15, P4: Giza 113, P5: Dorado, H1: (P1 × P2), H2: ( P1 × P3), H3: (P2 × P3), H4: (P2 × P4), and H5: ( P3 $\times$ P4) M; DNA ladder (100-3000 bp) as marker and the molecular weight as follows: 100, 200, 300, 400, 500, 600, 700, 800, 900, 1000, 1500, and $3000 \mathrm{bp}$, respectively.

maintaining a reasonable level of photosynthesis to produce sufficient dry material to sustain life during this environmental challenge; in addition, these superior genotypes have recorded high and positive results for all studied traits under water deficit treatment compared with the control experiment. Similar results were in agreement with those reported by El-Mouhamady et al. (2010), El-Mouhamady et al. (2012A), El-Mouhamady et al. (2012B), El-Seidy et al. (2013), El-Mouhamady et al., (2014A), El-Mouhamady et al. (2014B), El-Mouhamady et al. (2014C), Asifa et al. (2015), Esmail et al. (2016), ElMouhamady et al. (2016), Eldessouky et al. (2016), Ramadan et al. (2016), Khatab et al. (2017), Madhukar et al. (2018), and Behboudi et al. (2018).
Plant breeders are concerned first and foremost with the improvement of quantitative traits which have a high economic cost such as high yield, resistance to various diseases, tolerance for high level of salinity, and resistance to water stress. This was the most important factor under study in determining production and productivity in this regard. We cannot dispense the expression of additive gene action, which was added by traditional breeding through isolation segregation generations by simple selection to trace these beneficial traits, particularly water deficit resistance. It is also the most important aspect of plant breeding to obtain the positive trends of the quantitative traits mentioned above. Half diallel analysis of parents and their hybrids under the two levels 
Table 11 Total bands produced from each primer for 10 sorghum genotypes and all amplified fragments in each genotype

\begin{tabular}{|l|l|l|l|l|l|l|l|l|l|}
\hline \multirow{2}{*}{ Genotypes } & \multicolumn{7}{|c|}{ Primers } \\
\cline { 2 - 11 } & SR-04 & SR-05 & SR-06 & SR-07 & SR-11 & SR-12 & SR-13 & SR-14 & Total \\
\hline P1 & 10 & 11 & 9 & 8 & 6 & 8 & 7 & 7 & 66 \\
\hline P2 & 10 & 15 & 12 & 9 & 9 & 13 & 12 & 12 & 92 \\
\hline P3 & 8 & 10 & 9 & 11 & 10 & 13 & 10 & 7 & 78 \\
\hline P4 & 12 & 11 & 13 & 12 & 10 & 14 & 12 & 11 & 95 \\
\hline P1 & 13 & 13 & 13 & 12 & 10 & 15 & 13 & 13 & 102 \\
\hline H2 & 10 & 15 & 14 & 12 & 9 & 15 & 11 & 13 & 99 \\
\hline H3 & 11 & 12 & 13 & 8 & 8 & 10 & 10 & 10 & 82 \\
\hline H4 & 10 & 12 & 17 & 12 & 10 & 15 & 14 & 12 & 102 \\
\hline H5 & 10 & 12 & 17 & 11 & 8 & 13 & 14 & 12 & 97 \\
\hline Total Bands & 105 & 125 & 130 & 106 & 89 & 130 & 113 & 109 & 907 \\
\hline
\end{tabular}

Table 12 Mapping of positive (P) and negative specific markers for the 10 sorghum genotypes using eight ISSR primers

\begin{tabular}{|c|c|c|c|c|c|c|c|c|c|c|c|c|}
\hline ISSR Primers & MS(bp) & P1 & $\mathbf{P 2}$ & P3 & P4 & P5 & H1 & H2 & H3 & H4 & H5 & (P or N) Marker \\
\hline SR-04 & 1671 & - & - & - & + & - & - & - & - & - & - & $\mathbf{P}(\mathbf{P 4})$ \\
\hline & 711 & - & - & - & - & + & - & - & - & - & - & $\mathbf{P}(\mathbf{P 5})$ \\
\hline & 324 & + & + & - & + & + & + & + & + & + & + & $\mathbf{N}(\mathbf{P 3})$ \\
\hline SR-05 & 1859 & - & + & - & - & - & - & - & - & - & - & $\mathbf{P}(\mathbf{P} 2)$ \\
\hline & 1627 & - & + & - & - & - & - & - & - & - & - & $\mathbf{P}(\mathbf{P} 2)$ \\
\hline & 1377 & - & - & - & + & - & - & - & - & - & - & $\mathbf{P}(\mathbf{P 4})$ \\
\hline & 913 & - & + & - & - & - & - & - & - & - & - & $\mathbf{P}(\mathbf{P} 2)$ \\
\hline & 840 & - & - & - & - & - & + & - & - & - & - & P(H1) \\
\hline & 790 & - & - & - & + & - & - & - & - & - & - & P(P4) \\
\hline & 320 & + & + & + & - & + & + & + & + & + & + & N(P4) \\
\hline SR-06 & 2131 & - & - & - & - & - & - & - & + & - & - & P(H3) \\
\hline & 1807 & - & - & - & - & - & - & - & + & - & - & $\mathbf{P}(\mathbf{H} \mathbf{3})$ \\
\hline & 1230 & - & + & - & - & - & - & - & - & - & - & $\mathbf{P}(\mathbf{P} 2)$ \\
\hline & 983 & - & - & - & - & - & - & + & - & - & - & $\mathbf{P}(\mathbf{H} \mathbf{2})$ \\
\hline & 889 & + & + & + & + & + & + & - & + & + & + & $\mathbf{N}(\mathbf{H} 2)$ \\
\hline & 208 & - & + & + & + & + & + & + & + & + & + & $\mathbf{N}(\mathbf{P 1})$ \\
\hline & 181 & + & - & - & - & - & - & - & - & - & - & $\mathbf{P}(\mathbf{P 1})$ \\
\hline SR-07 & 1346 & - & - & - & - & - & + & - & - & - & - & P(H1) \\
\hline & 463 & - & + & + & + & + & + & + & + & + & + & $\mathbf{N}(\mathbf{P 1})$ \\
\hline & 302 & - & - & - & - & - & + & - & - & - & - & $\mathbf{P}(\mathbf{H 1})$ \\
\hline SR-11 & 1213 & - & + & + & + & + & + & + & + & + & + & $\mathbf{N}(\mathbf{P 1})$ \\
\hline SR-12 & 1491 & - & + & & - & - & - & - & - & - & - & $\mathbf{P}(\mathbf{P} 2)$ \\
\hline & 560 & + & + & + & + & + & + & - & + & + & + & $\mathbf{N}(\mathbf{H} 2)$ \\
\hline SR-13 & 529 & - & - & - & - & - & - & - & - & - & + & P(H5) \\
\hline & 281 & - & - & - & + & - & - & - & - & - & - & P(P4) \\
\hline & 254 & - & - & - & - & - & - & - & - & - & + & P(H5) \\
\hline SR-14 & 705 & - & + & - & - & - & - & - & - & - & - & $\mathbf{P}(\mathbf{P} 2)$ \\
\hline & 669 & - & + & + & + & + & + & + & + & + & + & $\mathbf{N}(\mathbf{P 1})$ \\
\hline & 277 & - & + & + & + & + & + & + & + & + & + & $\mathbf{N}(\mathbf{P 1})$ \\
\hline & 104 & + & + & - & + & + & + & + & + & + & + & N(P3) \\
\hline Range & 104-2131 & & & & & & & & & & & \\
\hline Total & & 6 & 16 & 8 & 13 & 11 & 13 & 9 & 12 & 10 & 12 & $30(20(\mathrm{P})+10(\mathrm{~N})$ \\
\hline
\end{tabular}


Table 13 Genetic similarity percentages of 10 sorghum entries using 8 ISSR primers

$\begin{array}{lllllllllll}0 & \text { P1 } & \text { P2 } & \text { P3 } & \text { P4 } & \text { P5 } & \text { H1 } & \text { H2 } & \text { H3 } & \text { H4 } & \text { H5 } \\ \text { P1 } & 1.0 & & & & & & & & & \\ \text { P2 } & 0.612 & 1.0 & & & & & & & & \\ \text { P3 } & 0.582 & 0.683 & 1.0 & & & & & & & \\ \text { P4 } & 0.490 & 0.654 & 0.632 & 1.0 & & & & & & \\ \text { P5 } & 0.527 & 0.701 & 0.621 & 0.824 & 1.0 & & & & & \\ \text { H1 } & 0.500 & 0.591 & 0.609 & 0.658 & 0.763 & 1.0 & & & & \\ \text { H2 } & 0.557 & 0.539 & 0.568 & 0.594 & 0.657 & 0.757 & 1.0 & & & \\ \text { H3 } & 0.460 & 0.577 & 0.551 & 0.683 & 0.743 & 0.689 & 0.614 & 1.0 & & \\ \text { H4 } & 0.509 & 0.575 & 0.521 & 0.548 & 0.644 & 0.647 & 0.598 & 0.761 & 1.0 & \\ \text { H5 } & 0.481 & 0.576 & 0.495 & 0.588 & 0.661 & 0.649 & 0.614 & 0.704 & 0.801 & 1.0\end{array}$

of irrigation (normal and water stress conditions) was intended to ensure that all genotypes using in this investigation were significantly or highly significantly different from each other and this was the main input of this genetic analysis, which has already been confirmed in Table 4 (Asifa et al. 2015, Esmail et al.
2016, El-Mouhamady et al. 2016, Ramadan et al. 2016, and Khatab et al. 2017).

Results presented in Table 5 confirmed the importance of (dominance gene action) and their interactions beside the major role of SCA effects for controlling and inheriting all studied traits for drought tolerance under normal

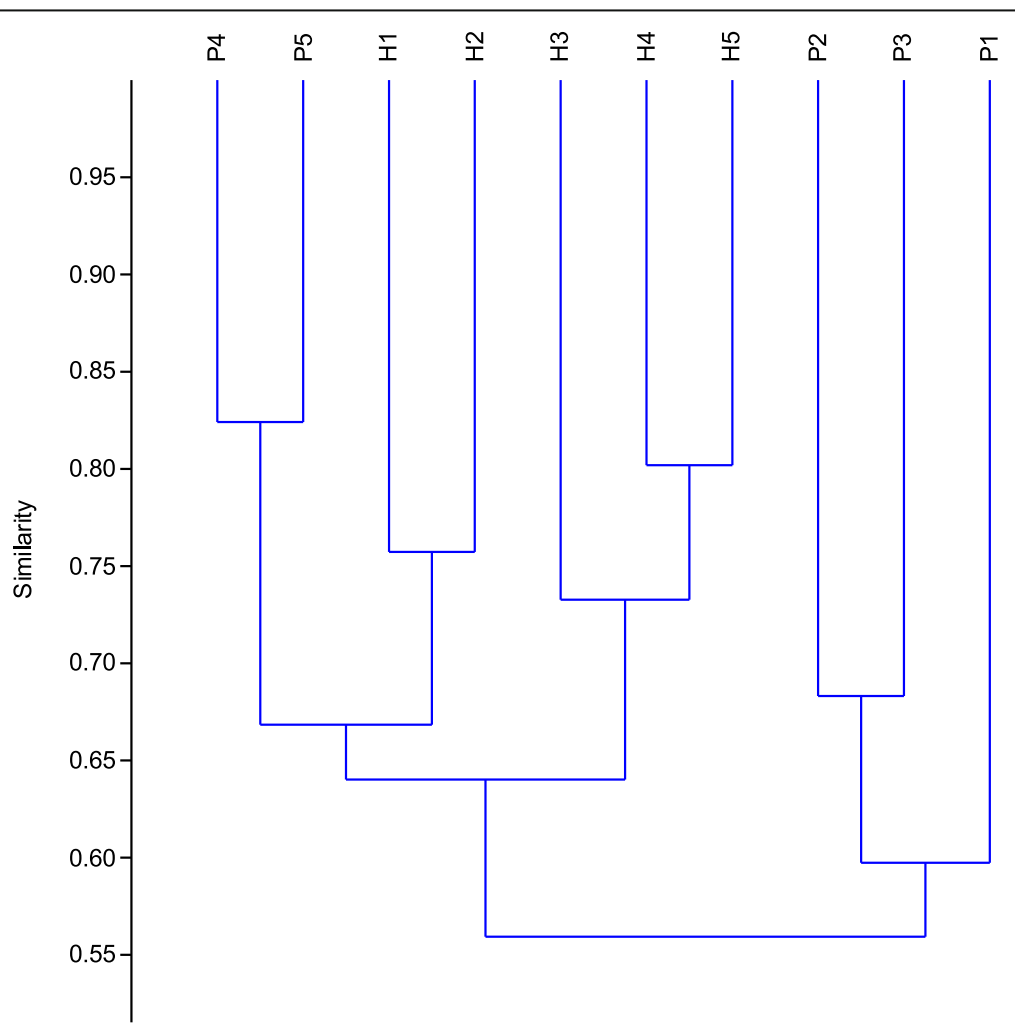

\section{UPGMA}

\section{Nei-Li's similarity coefficient}

Fig. 2 Dendrogram representing the genetic relationship among the ten wheat genotypes using UPGMA cluster analysis of Nei-Li's similarity coefficient generated from the eight ISSR markers 
and water stress conditions, which emphasizes the vital and effective role in improving water stress resistance in sorghum accessions and transferring this mechanism to unprecedented levels of tolerance under the Egyptian agriculture conditions. Heterosis over better-parent parameter is considered the best and most reliable method for sorting out superior and highly resistant entries because it simply aims to discuss the phenomenon of genetic superiority produced by transgression segregation, which has demonstrated the transmission of the excellent water stress resistance genes from the selected parents for the hybrid program to the five superior crosses for water deficit tolerance depending on all data calculated for all studied traits under drought stress compared to the control treatment of irrigation. Thus, this regard has given the way to ascertain the effective role played by dominance gene action and its interactions for inheriting the previous traits as well as the moral participation in improving water stress tolerance. Similar results were obtained by Esmail et al. (2016), El-Mouhamady et al. (2016), Eldessouky et al. (2016), Ramadan et al. (2016), Khatab et al. (2017), and Khatab et al. (2019).

Based on half diallel analysis, it must be recognized that the GCA effects have given the opportunity to additive gene action and its various interactions to express the success of the five sorghum accessions used in this investigation, especially the first three lines compatible with each other and giving a group of excellent crosses for water stress tolerance compared to these traits studied, especially grain yield/plant, maximum root length, number of roots/plant, root dry weight, and proline and chlorophyll contents and the rest of the traits in this regard. For SCA effects, we note that the five previous promising hybrids which have excelled for heterosis over better parent and SCA effects can continue to be cultivated and evaluated for several generations under the normal and drought conditions with simple selection after each segregation generation to reach to the maximum genetic stability that can be achieved and in finally obtaining lines that are highly yielding, resistant to disease, and tolerant to salinity and water deficit under Egyptian conditions. These results were in agreement with those reported by El-Mouhamady (2003), El-Mouhamady (2009), El-keredy et al. (2003), Esmail et al. (2016), El-Mouhamady et al. (2016), Eldessouky et al. (2016), Ramadan et al. (2016), Khatab et al. (2017), and Khatab et al. (2019).

The data of heritability in a broad sense for all traits tested revealed results higher than $99.50 \%$ or almost $100 \%$ under all conditions which discussed that genetic variance was very highly solely and primarily responsible for inheriting the former traits and boosting the ability for water stress resistance in sorghum accessions, extension to the impact of environmental variance which was very weak for all studied traits, and all entries highly varied among them. Furthermore, the data of heritability in a narrow sense showed medium values for all studied traits under both conditions which affirmed that additive variance had an average influence on controlling and inheriting the previous studied traits under normal and water deficit conditions. Results shown in Table 8 mentioned that RI was near from $50 \%$ or slightly larger, but it was moderately influential and matched with heritability in a narrow sense in all traits under testing under both treatments of irrigation, which emphasized that additive variance was recorded with extraordinary effort for controlling the previous traits and stimulating and reinforcing water deficit resistance in sorghum plants, and additive gene action was participating for metering genetic variance with intermediate shape. The data of GCV\% attained the prime part of PCV\%, where the values were up to $99.90 \%$ from the total amount of PCV\% which confirmed that genotypic variance was the greatest item in phenotypic variance and answerable for controlling and inheriting the previous underestimated traits; aside from raising the level of water stress tolerance in sorghum genotypes under local conditions, environmental variance did not have an impact on dominating the anterior traits. These findings were exhibited by El-Mouhamady et al. (2017) and El-Demardash et al. (2017).

Tolerance index test confirmed that the mentioned accessions in their context were the true secretion for the genes responsible for water deficit resistance in sorghum genotypes which will be integrated into the next segregation generations by continuing in growing it beside the simple selection for the best plants across these generations to achieve desired genetic stability and high yielding as well as resistance and tolerance for adverse environmental conditions such as water poverty because it simply showed a positive trend in reducing the rate of yielding loss under this stress and this genetic behavior did not occur in the rest of the entries under the same conditions (Nazari and H. Pakniyat 2010, Abdi H et al. 2012, El-Mouhamady et al., 2012a, b, El-Seidy et al., 2013, Kumar et al. 2015, Esmail et al. 2016, Ramadan et al. 2016, Khatab et al. 2017, El-Demardash et al. 2017, and Khatab et al. 2019).

Results obtained from Table 10 and Fig. 1 confirmed that the highest number of amplicons were showed in primers SR-05 and SR-06 where they achieved 27 fragments for both of them; besides, they revealed the biggest polymorphism percentages $(96.29 \%$ and $85.18 \%)$ for them, respectively, while the SR-11 primer recorded the lowest number of amplicons (10) and polymorphism (40\%). These results confirmed that the previous primers succeeded for determining the molecular differences among the ten sorghum genotypes which were considered as a taxonomic basic for drought resistance in this 
regard. Similar results were in agreement with those reported by El-Mouhamady et al. (2014D), Esmail et al. (2016), Ramadan et al. (2016), Khatab et al. (2017), and Khatab et al. (2019).

Molecular markers using ISSR analysis have succeeded in determining the specific markers responsible for the differentiation among the ten sorghum genotypes, noting that these specific markers have been considered as a taxonomic basis among the recent entries and a major cause of bearing these genotypes for water deficit conditions (Tables 11 and 12). These results were obtained by Ramadan et al. (2016), Esmail et al. (2016), Eldessouky et al. (2016), Khatab et al. (2017), and Khatab et al. (2019).

It is noted that the genetic similarity observed between $\mathrm{P} 4$ and $\mathrm{P} 5, \mathrm{H} 4$ and $\mathrm{H} 5$, and $\mathrm{P} 5$ and $\mathrm{H} 1$ recorded the best and highest relationships which indicated that P4, P5, $\mathrm{H} 1, \mathrm{H} 4$, and $\mathrm{H} 5$ genotypes are considered very genetically close from each other and can be used in breeding programs to develop and improve water deficit resistance in sorghum plants under Egyptian conditions (Table 13) (Esmail et al. 2016, Ramadan et al. 2016, Khatab et al. 2017, and Khatab et al. 2019).

Cluster analysis showed the genetic affinity and divergence of the ten sorghum accessions. This directly contributed to the actual result of the success of the hybridization process, as well as the identification of genetically compatible genotypes in terms of growth so as to grow more clearly together in segregation generations which will enable for selecting the strongest genotype resistance for drought stress and introducing them in the breeding program to produce resistant sorghum lines of this dangerous environmental factor as well as choosing the best parents in terms of high yield and resistance for many diseases (Fig. 2) (Esmail et al. 2016, Ramadan et al. 2016, Khatab et al. 2017, and Khatab et al. 2019).

\section{Conclusion}

The present investigation was carried out in the farm of Nubaria in Behira Governorate, Egypt, using five sorghum entries and their ten F1 crosses by half diallel analysis under normal and water stress conditions during the 2017 and 2018 seasons. The aim of this study is determining mechanisms responsible for water deficit tolerance in sorghum plants and producing some hybrids very resistant to this stress besides continuing to grow them for several generations to reach high genetic stability and resistance for water stress. This step will be the intent of using in plant breeding programs to transfer resistance genes to sensitive local varieties besides high yield. Some physiological traits were used as an index for drought tolerance; in addition, ISSR analysis technique was used to identify within the five sorghum parents and the best of their five crosses depending on the results obtained from all physiological traits. The final results confirmed that genotypes $(\mathrm{P} 1, \mathrm{P} 2, \mathrm{P} 3, \mathrm{P} 1 \times \mathrm{P} 2, \mathrm{P} 1 \times \mathrm{P} 3$, $\mathrm{P} 2 \times \mathrm{P} 3, \mathrm{P} 2 \times \mathrm{P} 4$, and $\mathrm{P} 3 \times \mathrm{P} 4)$ exhibited high resistance to water stress and achieved the most desirable data for all traits under study for both treatments of irrigation. Eight ISSR primers generated 151 amplicons (38 of them were monomorphic and 113 polymorphic including 20 unique bands) with $74.83 \%$ polymorphism.

\section{Significance statement}

This study discovered the nucleus used for producing the most sorghum genotype resistance for water deficit stress in the future through estimating some parents and their F1 crosses resulting from half diallel analysis under normal and drought conditions and estimating some important indicators related to water stress resistance in this crop that can be beneficial for the breeder who uses plant breeding programs for the improvement of sorghum plants for drought tolerance. This study will help to uncover the critical area of breeding for water deficit tolerance in sorghum that many researchers were not able to explore. Thus, the new theory on low values of osmotic pressure and $\Delta T$ traits as well as high levels of proline content and SPAD values in leaves of sorghum plants under stress may have a strong relationship with drought resistance in sorghum.

\section{Abbreviations}

DSI: Drought susceptibility index; DTI: Drought tolerance index; GMP: Geometrical mean productivity; GY/P: Grain yield/plant; GYD: Mean yield under drought conditions; GYP: Mean yield under normal conditions; MP: Mean productivity; MRL: Maximum root length; No. of R/P: Number of roots/plant; OP: Osmotic pressure; Proline C.: Proline content; RDW: Root dry weight; SPAD values: Chlorophyll content; YI: Yield index; Yr: Yield reduction ratio; YSI: Yield stability index; $\Delta T$ : Temperature of canopy - temperature of air

\section{Acknowledgements}

Not applicable.

\section{Authors' contributions}

RST did the part on molecular markers and reviewed the full paper (50\% contribution). ABAEM did the part on plant breeding which included hybridization and sowing, and reviewed the full paper (50\% contribution). Both authors read and approved the final manuscript.

\section{Funding \\ Not applicable.}

\section{Availability of data and materials}

The datasets used and/or analyzed during the current study are available from the corresponding author on reasonable request.

\section{Ethics approval and consent to participate}

Not applicable.

Consent for publication

Not applicable.

Competing interests

The authors declare that they have no competing interests. 


\section{Author details}

'Department of Plant Biotechnology, Genetic Engineering and Biotechnology Division, National Research Centre, 33 El Buhouth ST, 12622, Dokki, Giza, Egypt. ²Department of Genetics and Cytology, Genetic Engineering and Biotechnology Division, National Research Centre, $33 \mathrm{El}$ Buhouth ST, 12622, Dokki, Giza, Egypt.

Received: 9 April 2019 Accepted: 28 June 2019

Published online: 23 July 2019

\section{References}

Asifa K, Soomro ZA, Mari SN, Sial MA, Baloch M (2015) Assessing yielding ability of wheat genotypes under water deficient state. Int J Biol Bio 12:247-259

Bates LS, Waldren RP, Teare ID (1973) Rapid determination of free proline for water-stress studies. Plant Soil 39:205-207

Behboudi F, Sarvestani ZT, Kassaee MZ, Sanavi SAMM, Sorooshzadeh A, Ahmadi SB (2018) Evaluation of chitosan nanoparticles effects on yield and yield components of barley (Hordeum vulgare L.) under late season drought stress. J. Water Envi Nano 3:22-39

Betran FJ, Beek D, Banziger M, Edmeades GO (2003) Genetic analysis of inbred and hybrid grain yield under stress and non-stress environments in tropical maize. Crop Sci 43:807-817

Bouslama M, Schapaugh WT (1984) Stress tolerance in soybean. Part 1: evaluation of three screening techniques for heat and drought tolerance. Crop Sci 24: 933-937

Chinard FP (1952) Photometric estimation of proline and ornithine. J. Biol Chem. 199(1):91-95

El- Demardash IS, El-Mouhamady AA, Abdel- Rahman HM, Elewa TA, Aboud KA (2017) Using gamma rays for improving water deficit tolerance in rice. Cur Sci Int 6:321-327

Eldessouky EIS, Heiba SAA, El-Mouhamady AA, Abdel-Tawab YM (2016) DNA fingerprinting and half diallel analysis of some rice genotypes under water deficit conditions. RJPBCS 7:985-997

El-Keredy MS, Draz AE, Ragab AY, Abdallah AA, El-Mouhamady AA (2003) Combining ability for some quantitative characters in rice (Oryza sativa L.) under normal and saline soil conditions. The tenth conf of agro Octo Suez Canal Univ El-Irish Egypt 9:7-10

El-Mouhamady AA (2003) Breeding studies for salt tolerance in rice. Tan Uni Bra Kafr- She Fac Agric Egypt

El-Mouhamady AA (2009) Breeding for drought tolerance in rice. Ph. D Thesis Fac Agric Kafr-Shei Univ Egypt

El-Mouhamady AA, Abdel-Rahman HM, Elewa TA, Aboud KA (2017) Molecular characterization and stability analysis for yield and its components traits in soybean (Glycine max L.). Int J Curr Microbiol App Sci 6:1835-1857

El-Mouhamady AA, Amer Kh A, Ragab AY (2012a) Development of salinity tolerance in some genotypes of barley using line $x$ tester analysis and some techniques of biotechnology. J of Appl Sci Res 8:972-982

El-Mouhamady AA, El-Ashary ZM, Mohamed Fl, Elewa TA, Aboud KA (2016) Study the effect of water stress conditions on some genotypes of bread wheat (Triticum aestivum L.) based on morphological, physiological traits and DNA fingerprinting. Res J Pharma Biol Chem Sci 7:2065-2077

El-Mouhamady AA, El-Demardash IS, Aboud KA (2010) Biochemical and molecular genetic studies on rice tolerance to salinity. J of Am Sci 6:521-535

El-Mouhamady AA, El-Seidy EH, Aboud KA (2012b) Identification of a molecular markers linked to drought tolerance in some genotypes of barley. Aus J of Bas and App Sci 6:196-204

El-Mouhamady AA, El-Seidy EH, El-Ekhtyar AM, Elewa TA (2014C) Molecular markers and physiological traits linked to salinity tolerance in rice. Int J.of Aca Res Part A July 6(4):195-205

El-Mouhamady AA, El-Seidy EH, Elewa TA (2014d) Using molecular markers to study mechanics responsible for drought tolerance in some genotypes of sorghum. Int J Curr .Microbiol App Sci 3(8):481-491

El-Mouhamady AA, El-Seidy EH, Elewa TA, Aboud KA (2014a) Studies on breeding for drought tolerance in some promising lines of sugar beet (Beta vulgaris L.). Mid East J of Appl Sci 4(3):718-732

El-Mouhamady AA, Rady MR, El-Seidy EH (2014b) Assessment of genetic variability for six lines of wheat using physiological traits and molecular markers technique under normal irrigation and water stress conditions. Wor Appl Sci J 29(4):506-516
El-Seidy EH, El-Mouhamady AA, Aboud KA (2013) Studies on the modification of gene expressionwhich responsible for salinity tolerance in some genotypes of wheat. Int J of Acad Res Part A 5:23-32

Esmail RM, Abdel Sattar AA, Abdel-samea NS, El-Mouhamady AA, Abdelgany EM, Fathallaha FB (2016) Assessment of genetic parameters and drought tolerance indices in maize diallel crosses. Res J Pharm Biol Chem Sci 7:2409-2428

Falconar DS, Mackay TFC (1996) Introduction to quantitative genetics. Chapman and Hall London UK

Fernandez GCJ (1992) Effective selection criteria for assessing plant stress tolerance. Proc of on the Sym Taiw 25:257-270

Fischer RA, Maurer R (1978) Drought resistance in spring wheat cultivars. I Grain yield response. Aust J Agric Res 29:897-907

Gavuzzi P, Rizza F, Palumbo M, Campaline RG, Ricciardi GL, Borghi B (1997) Evaluation of field and laboratory predictors of drought and heat tolerance in winter cereals. Can J Plant Sci 77:523-531

Gezahegn G, Kassahun T, Endashaw B (2010) Inter simple sequence repeat (ISSR) analysis of wild and cultivated rice species from Ethiopia. Afri J of Biot 9: 5048-5059

Golestani SA, Assad MT (1998) Evaluation of four screening techniques for drought resistance and their relationship to yield reduction ratio in wheat. Euphyt-ica 103:293-299

Gosev NA (1960) Some methods in studying plant water relation. Leningrd Acadd of Sci USSR

Griffing JB (1956) Concept of general and specific combining ability in relation to diallel crossing systems. Aust J of Biol Sci 9:463-493

Hossain ABS, Sears AG, Cox TS, Paulsen GM (1990) Desiccation tolerance and its relationship to assimilate partitioning in winter wheat. Crop Sci 30:622-627

Jabereldar AA, El Naim AM, Dagash YM, Abdalla AA, Ahmed SE (2017) Effect of water stress on drought tolerance index of sorghum (Sorghum bicolor I. Moench) in North Kordofan state. UKJNRES 10:11-20

Jaccard P (1908) Nouvelles Researchers Sur La IstributionLorale. Bull Soc Vaud Sci Nat 44:223-270

Kalindee S, Shinde, Borkar SG (2018) Seed bacterialization induced proline content in Sorghum bicolor crop under severe drought condition. Int J of Chem St 6:1191-1194

Khatab Al, El-Mouhamady AA, Mariey SA, Elewa TA (2019) Assessment of water deficiency tolerance indices and their relation with ISSR markers in barley (Hordeum vulgare L.). Cur Sci Int 8(1):83-100

Khatab IA, El-Mouhamady AA, Abdel-Rahman HM, Farid MA, El-Demardash IS (2017) Agro-morphological and molecular characterization of sorghum (Sorghum vulgare L.) for water stress tolerance. Int J Curr Res Biosci Plant Biol 4:37-55

Kumar R, Kaul J, Dubey RB, Singode A, Manivannan A, Debnath MK (2015) Assessment of drought tolerance in maize (Zea mays L.) based on different indices. Sabrao J Breed Genet 47:291-298

Lin CS, Binns MR, Lefkovitch LP (1986) Stability analysis: where do we stand? Crop Sci 26:894-900

Madhukar K, Prasad LC, Lal JP, Prasad R, Chandra K (2018) Generation mean analysis for yield and drought related traits in barley (Hordeum vulgare L.). Int J Pure App Bio Sci 6:1399-1408

Pinheiro CL, Araújo HTN, Brito SFD, Maia MDS, Viana JDS, Filho SM (2018) Seed priming and tolerance to salt and water stress in divergent grain sorghum genotypes. Am J of Plant Sci 9:606-616

Ramadan WA, Abdel-Rahman HM, El-Mouhamady AA, Habouh MAF, Aboud KA (2016) Molecular genetic studies on some barley genotypes for drought tolerance. Int J Pharm. Tech. Res 9:265-285

Sambrook J, Fritsch KF, Maniatis T (1989) Molecular cloning, Second edn. cold spring Harbor New York

Too EJ, Onkware AO, Were BA, Carlsson SGA, Geleta M (2018) Molecular markers associated with aluminium tolerance in Sorghum bicolor. Here 155:1-13

Verma R, Kumarand R, Nath D (2018) Drought resistance mechanism and adaptation to water stress in sorghum [Sorghum bicolor (L.) Moench]. Int 」 of Bio-res and Str Man 91:167-172

Zietkiewicz E, Rafalski A, Labuda D (1994) Genome fingerprinting by simple sequence repeats (SSR)-anchored polymerase chain reaction amplification. Geno 20:176-183

\section{Publisher's Note}

Springer Nature remains neutral with regard to jurisdictional claims in published maps and institutional affiliations. 